\title{
Marginal microleakage of class II composite resin restorations due to restorative techniques
}

\author{
Microinfiltração marginal de restaurações classe II de resina \\ composta devido às técnicas restauradoras
}

\begin{abstract}
Purpose: To evaluate the marginal microleakage of class II composite resin (CR) restorations due to restorative techniques.

Methods: Forty human extracted premolars were assigned to 4 groups $(n=10)$. Class II cavities were prepared (4-mm wide, 2-mm axially, with the gingival margin located $1 \mathrm{~mm}$ beyond the cementum-enamel-junction), and the restorative adhesive system Prime \& Bond 2.1/TPH (Dentsply) was used. CR was inserted by the oblique incremental technique (OIT) and cured in continuous exposure. The restoratives techniques were: group 1 (control): OIT; group 2: flowable resin $(1 \mathrm{~mm})$ applied in the gingival wall + OIT; group 3: OIT + three pre-cured spheres inserted in the first increment of CR; and, group 4: OIT + strip of fiberglass inserted in the first increment of $C R$. The specimens were subjected to a thermocycling regimen of 500 cycles ( $1 \mathrm{~min}$ at $5^{\circ}-37^{\circ}-55^{\circ} \mathrm{C}$ ), coated with two layers of nail varnish up to $1 \mathrm{~mm}$ from the restoration margins, and immersed in $0.5 \%$ basic fuchsine solution for $24 \mathrm{~h}$. The extension of dye penetration at the cervical wall $(\mu \mathrm{m})$ was evaluated using an optic microscope at $x 40$. Data were analyzed using analysis of variance (ANOVA) $(\alpha=0.05)$.

Results: The microleakage values were: $\mathrm{G} 1: 370 \mu \mathrm{m} \pm 241 ; \mathrm{G} 2: 398 \mu \mathrm{m} \pm 354 ; \mathrm{G} 3$ : $205 \mu \mathrm{m} \pm 119$; and $\mathrm{G} 4: 413 \mu \mathrm{m} \pm 340$. No statistically significant differences were found among the restorative techniques $(P=0.081)$.

Conclusion: Marginal microleakage values were not influenced by the different restorative techniques tested.
\end{abstract}

Key words: Composite resin; marginal microleakage; restorative technique

\section{Resumo}

Objetivo: Avaliar a microinfiltração marginal de restaurações classe II de resina composta (RC) em função de técnicas restauradoras.

Metodologia: Quarenta pré-molares humanos extraídos foram divididos em 4 grupos $(\mathrm{n}=10)$. Cavidades classe II foram preparadas $(4 \mathrm{~mm}$ de largura, $2 \mathrm{~mm}$ de altura e margem gengival localizada a $1 \mathrm{~mm}$ além da junção amelo-cementária, e foi usado o sistema adesivo Prime \& Bond 2.1/TPH ${ }^{3}$ (Dentsply). A RC foi inserida pela técnica incremental oblíqua (OIT) e polimerizada em exposição contínua. As técnicas restauradoras foram: grupo 1 (controle): OIT; grupo 2: resina fluida $(1 \mathrm{~mm})$ aplicada na parede gengival + OIT; grupo 3: OIT + três esferas pré-polimerizadas no primeiro incremento de RC; e grupo 4: OIT + tira de fibra de vidro inserida no primeiro incremento de RC. Os espécimes foram submetidos à termociclagem por 500 ciclos $\left(1 \mathrm{~min}\right.$ a $5^{\circ}-37^{\circ}-55^{\circ} \mathrm{C}$ ), cobertos com duas camadas de esmalte até $1 \mathrm{~mm}$ das margens da restauração e imersos em solução de fucsina básica a 0,5\% por 24 h. A extensão da penetração do corante na parede cervical $(\mu \mathrm{m})$ foi avaliada com microscópio ótico $(x 40)$. Os dados foram analisados por ANOVA $(\alpha=0,05)$.

Resultados: Os valores de microinfiltração foram: $\mathrm{G} 1: 370 \mu \mathrm{m} \pm 241$; G2: $398 \mu \mathrm{m} \pm 354$; G3: $205 \mu \mathrm{m} \pm 119$ e G4: $413 \mu \mathrm{m} \pm 340$. Não houve diferença estatisticamente significativa entre as técnicas restauradoras $(P=0,081)$.

Conclusão: Os valores de microinfiltração marginal não foram influenciados pelas diferentes técnicas restauradoras neste estudo.

Palavras-chave: Resina composta; microinfiltração marginal; técnica restauradora

\author{
Andreia A. Carvalho a \\ Francine C. L. Moreira ${ }^{b}$ \\ Larissa $M$. Cunha ${ }^{c}$ \\ Samara M. de Moura ${ }^{c}$ \\ João Batista de Souza d \\ Carlos Estrela e \\ Lawrence G. Lopes e
}

a Post-graduate Program, School of Dentistry, Federal University of Goiás, Goiânia, GO, Brazil b Department of Prevention and Oral Rehabilitation, School of Dentistry, Federal University of Goiás, Goiânia, GO, Brazil

c School of Dentistry, Federal University of Goiás, Goiânia, GO, Brazil

d Department of Prevention and Oral Rehabilitation, School of Dentistry, Federal University of Goiás, Goiânia, GO, Brazil

e Department of Prevention and Oral Rehabilitation, School of Dentistry, Federal University of Goiás, Goiânia, GO, Brazil

\author{
Correspondence: \\ Lawrence Gonzaga Lopes \\ Department of Prevention and Oral Rehabilitation \\ School of Dentistry - Federal University of Goias \\ Praça Universitária esq. c/ $1^{a}$ Avenida s/n - \\ Setor Universitário \\ Goiânia, GO - Brazil \\ 74605-220 \\ E-mail: drlawrenceg@yahoo.com.br
}

Received: December 30, 2009

Accepted: March 31, 2010

Conflict of Interest Statement: The authors state that there are no financial and personal conflicts of interest that could have inappropriately influenced their work. The materials were donated by Dentsply.

Copyright: (c) 2010 Carvalho et al.; licensee EDIPUCRS. This is an Open Access article distributed under the terms of the Creative Commons AttributionNoncommercial-No Derivative Works 3.0 Unported License. 


\section{Introduction}

The demand for esthetic restorative materials has greatly increased in recent years. However, for class II cavities, the factors primarily responsible for microleakage problems are related to the initial shrinkage stress of the composite resin (CR), the difference between the coefficient of thermal expansion of materials with hard dental tissue, the inaccessibility of the cervical area and, in particular, problems of bonding to the cervical substrate (1).

Microleakage may be defined as the passage of bacteria, fluids, molecules or ions between the cavity wall and the restorative material applied to it (2). These events may affect the property of the materials, resulting in recurrent caries, or causing post operative sensibility (3). Obviously, the longevity of the restoration may also be compromised.

Polymerization shrinkage is a complex process depending on several factors. The volumetric contraction causes debonding forces at the material/tooth interface (3). The stress resulting from this shrinkage has been associated with open margins between the restoration and the tooth, overt tooth straining or fracture, and post operative sensitivity $(3,4)$. Adhesive failure can also occur at the internal interface, leading to the formation of an internal gap between the material and the dentin surface (2). Such openings or gaps are considered deleterious since they allow the transit of fluid between the dentin-pulp complex and the oral environment $(3,5,6)$. Thus, different restorative techniques have been proposed to improve the adaptation marginal, such as pre-cured CR spheres inserted with the composite increments (7), a thin layer of flowable resin applied at the gingival wall and a strip of fiberglass inserted with the increments of $\operatorname{CR}(8,9)$.

The aim of this study was to evaluate the marginal microleakage of $\mathrm{CR}$ restorations as a function of different restorative techniques. The null hypothesis was that there are no differences in marginal microleakage of $\mathrm{CR}$ with respect to restorative techniques.

\section{Methodology}

The present study was approved by the Research Ethics Committee of the Federal University of Goias - COEP/UFG (Protocol number 076/06).

Forty sound, non-carious human premolar teeth extracted due to orthodontic reasons, were used in this study. The teeth were immersed in a $0.05 \%$ thymol solution for no longer than 6 months. Class II cavities were done using a drill \#245 (KG Sorensen Ind. Com. Ltda, Barueri, SP, Brazil), in high-speed turbine under water coolant (Kavo do Brasil Ind. Com. Ltda, Joinville, SC, Brazil). The mesial surface of each tooth was prepared, and the cavities (vertical slot) were standardized in the following dimensions: 4-mm wide, 2-mm axially, with the gingival margin located $1 \mathrm{~mm}$ beyond the cementumenamel-junction (CEJ). Prior to the restorative procedures, prophylaxis with pumice stone and water was performed. The 40 premolars were randomly assigned to 4 groups of ten teeth each according to the different experimental conditions.
Dentin and enamel were etched with $35 \%$ phosphoric acid gel (Denstply Ind. Com. Ltda, Petrópolis, RJ, Brazil) for $30 \mathrm{~s}$ in enamel and $15 \mathrm{~s}$ in cementum and dentin, followed by water spray for $30 \mathrm{~s}$ and drying with absorbent paper, leaving the surface visibly moist. The Prime \& Bond 2.1 (Denstply Ind. Com. Ltda) adhesive system was applied with a microbrush for $20 \mathrm{~s}$ and gently air dried. A slight drying using a triple air syringe was performed at $10-\mathrm{cm}$ distance for $5 \mathrm{~s}$ before the application of a new adhesive layer. A visible light-curing quartz-tungsten-halogen unit (Ultralux; Dabi Atlante, Ribeirão Preto, SP, Brazil) was used at continuous intensity of $500 \mathrm{~mW} / \mathrm{cm}^{2}$. The adhesive system was cured for $40 \mathrm{~s}$.

The polyester matrix was adapted and fixed with adhesive tape in the cervical region. All cavities were filled with a microhybrid composite resin (TPH ${ }^{3}$; Denstply Ind. Com. Ltda). The 40 teeth had approximately the same size. In order to standardize the volume of each increment to be used (5 increments per tooth), the cavity was filled entirely with $\mathrm{CR}$. Then, the resin was removed from the preparation and divided into five equal parts. A matrix of acrylic resin was made ( $1 / 5$ of total volume of the prepared cavity) to standardize the $\mathrm{CR}$ increment before its application into the cavity.

\section{Group 1 - Control group}

The teeth were restored with the oblique incremental technique (OIT), where the first increment was placed horizontally, i.e., the resin composite was applied directly on the gingival wall of the cavity without any combination of materials. The other increments were inserted so that the wall did not join the vestibular and palatal/lingual surfaces. Each increment was cured for $20 \mathrm{~s}$ followed by $40 \mathrm{~s}$ on the occlusal, buccal and lingual sides.

\section{Group 2 - Flowable composite}

The first increment was a layer of $1 \mathrm{~mm}$ resin flow (Fill Magic Flow; Vigodent SA Ind. Com., Rio de Janeiro, RJ, Brazil) applied directly on the gingival wall of the cavity using the fine tip of a syringe that accompanies the material. Then, curing was performed for $20 \mathrm{~s}$, and four more increments of CR were inserted into the cavity by OIT. Each increment was cured for $20 \mathrm{~s}$, and the final restoration was cured for $40 \mathrm{~s}$ on each side similarly to the control group.

\section{Group 3 - Pre-cured spheres}

The pre-cured spheres with diameter of $1 \mathrm{~mm}$ was confectioned to be used in restorative technique. The teeth were restored with OIT, with three pre-cured spheres in the first increment of CR that were applied on the gingival wall. The increment was cured for $20 \mathrm{~s}$. The other increments were done without pre-cured spheres, and were cured as in the control group.

\section{Group 4 - Fiberglass}

The teeth were restored with a $3 \times 2 \mathrm{~mm}$ strip of glass fiber locked Interlig (Angelus, Londrina, Paraná, Brazil), which 
was positioned in the first increment of CR cured for $20 \mathrm{~s}$. The remaining four increments of CR were inserted by using OIT and cured as in the other groups.

After the restorations were finished, all groups were stored in distilled water at $37^{\circ} \mathrm{C}$ for $48 \mathrm{~h}$. The polishing/finishing procedures were performed using a sequential series of aluminum oxide disks (Sof-Lex; 3M/ESPE, Sumaré, SP, Brazil). Afterwards each tooth was dried with absorbent paper, and two layers of cyanocrylate resin Super Bonder (Henkel Ltda, Itapevi, SP, Brazil) were placed in the root apex to seal it. The specimens were immersed in physiological solution at $37^{\circ} \mathrm{C}$ for $24 \mathrm{~h}$.

The four groups were subjected to a thermocycling regimen of 500 cycles with 1-min immersions in distilled water at $37^{\circ} \mathrm{C}, 5^{\circ} \mathrm{C}, 37^{\circ} \mathrm{C}$ and $55^{\circ} \mathrm{C}$. The teeth were coated with two layers of nail polish to leaving $1 \mathrm{~mm}$ from the resin/ tooth interface margins and were immersed in a $0.5 \%$ basic fuchsine solution for $24 \mathrm{~h}$. All teeth were included in orthoftalic transparent resin (T 208; Redefibra, São Paulo, SP, Brazil) to be sectioned longitudinally to a mesiodistal direction. In order to analyze the extent of leakage in the cervical wall $(\mu \mathrm{m})$, the slice that showed the highest degree of dye penetration per group was selected for observation under alternate microscopic high-power fields (x40) using an integration graticule (4740680000000-Netzmik-rometer 12.5, Carl Zeiss, 131 Göttingen, Germany). The extension of dye penetration were measured using this standard scale $(\mu \mathrm{m})$ located in the microscopy lenses by two calibrated examiners. The microleakage data were analyzed by analysis of variance (ANOVA) at the significance level of 0.05 .

\section{Results}

Table 1 displays the values of marginal microleakage according to the restorative technique. The analysis of variance showed that the restoration techniques did not influence the values of microleakage $(P=0.081)$. Although not statistically different, the group 3 (pre-cured spheres) had the lowest extent of penetration of the dye when compared with the other groups.

Table 1. Means ( \pm standard deviation - s.d.) of marginal microleakage of CR according to the restorative technique.

\begin{tabular}{lc}
\hline & $\begin{array}{c}\text { Marginal microleakage } \\
\text { Mean ( } \pm \text { s.d.) }\end{array}$ \\
\hline G1 - Control group & $370 \mu \mathrm{m}( \pm 241)$ \\
G2 - Flowable composite & $398 \mu \mathrm{m}( \pm 354)$ \\
G3 - Pre-cured spheres & $205 \mu \mathrm{m}( \pm 119)$ \\
G4 - Fiberglass & $413 \mu \mathrm{m}( \pm 340)$ \\
\hline
\end{tabular}

\section{Discussion}

For a higher longevity of the composite restoration, it is essential that the material provides good aesthetics and satisfactory physical, chemical and biological properties (6).
The CR is widely used in clinical practice, because of the aesthetic benefits, ease of use and bonding with the tooth structure (6). When applied in a cavity with the adhesive system, it establishes a proper interaction with the enamel and/or dentin, and the longitudinal stability is directly related to the steps resulting from cavity preparation, intrinsic characteristics of the adhesive and restorative materials, operational procedures and manipulative weather of the oral environment $(5,10)$.

Another important factor for CR refers to its mechanism of polymerization shrinkage (11). The marginal gap caused by the polymerization shrinkage may lead to pain on biting and failure of adhesion by repeated occlusal loading (6). In addition, cavity-wall gap formation may cause marginal staining, postoperative sensitivity and secondary caries $(4,6)$, although for Lima et al. (12) microleakage and surface roughness did not influenced caries lesion formation.

The adaptation of the material to the cavity depends essentially on their thermal expansion and dimensional changes during the process of polymerization $(2,13,14)$. Differences in the coefficient of linear thermal expansion between the dental restorative materials and structures are largely responsible for the leakage (2), which justifies the use of thermal cycling in this work $(11,15)$. Theoretically, the greater the difference between the coefficient of thermal expansion of the restorative material and the tooth, the greater the marginal leakage that occurs during temperature changes (15). On the other hand, Cenci et al. (16) evaluated the influence of thermal stress on the marginal integrity of restorative material with different adhesive and thermal properties. They concluded that CR was only affected in extreme situations, which are not present in normal oral conditions. In present study the specimens were leaved for $1 \mathrm{~min}$ in each temperature.

The class II cavities were confectioned only in one part of the teeth, since the photo-curing of the resin restoration could be to influence the shrinkage stress generation on the restoration of the other side. In class II cavities, another factor that significantly influences the marginal fit is the location of cervical margin $(5,17)$. If the margins are localized around $1.0 \mathrm{~mm}$ coronal to the CEJ a good marginal integrity may result following a conventional enamel acid etching (17). Soares et al. (18) evaluated the marginal integrity and microleakage of direct and indirect composite inlays in cavities with cervical finishing line prepared in dentine or enamel. There were no significant differences between the direct and indirect techniques for the cervical finishing line in enamel, but for the finishing line in dentin, the indirect technique allowed less microleakage than the direct technique. Thus, the authors decided to assemble the end cervical cavities with $1 \mathrm{~mm}$ below the CEJ, as are those most likely to microleakage and therefore there is greater need for studies to obtain satisfactory restorations (18). The dimensions of the cavity used in the present study were chosen because they represent the modern cavities that are indicated in the clinical practice. 
Dye penetration test are known to be valid tools for the determination of marginal gaps in vitro studies (19). It is an established method for the determination of marginal leakage in vitro, mostly performed after cutting the teeth in a longitudinal direction (19). However, the longer the penetration time is, the higher might be a risk of dye diffusion into the adhesive resulting in stained adhesive layers might be interpretated as gaps (19). The immersion in basic fuchsine solution for $24 \mathrm{~h}$ appears to be sufficient time for assessment of leakage with no impairment of adhesive interface, which is in agreement with the work of Cenci et al. (16) and Pazinatto et al. (20).

Knowing that the CR suffers shrinkage, it is important the clinical use of technical resources to try to minimize this problem, with the aim of obtaining a proper marginal sealing (3). For this, some factors involving the material and operative technique should be considered, such as the volume of $\mathrm{CR}$ inserted in the cavity and association of $\mathrm{CR}$ to other materials, whose properties are more suitable for application in the cervical area (10).

Li et al. (21), on work done in class $\mathrm{V}$ cavities with gingival margins in dentin/cementum, concluded that low viscosity CR can improve the marginal adaptation in dentine restorations in this type of cavity. Chuang et al. (22) investigated the influence of flowable composite in different thicknesses as marginal and internal porosity of class II restorations with CR. They concluded that the group with a thin layer of flowable composite $(0.5 \mathrm{a} 1 \mathrm{~mm})$ exhibited superior marginal quality in interface microleakage evaluation compared to the other groups (22). Alonso et al. (23) evaluated the effect of an adhesive applied in layers of different thickness or in association with a filled adhesive or with a low viscosity composite on the microleakage of composite restorations. The group in which was used application of one layer of adhesive followed by application of flowable composite showed less leakage than group in which there was only the application of one layer of adhesive (23). The authors concluded that the use of resin liners with flowable composites can reduce the microleakage of composite restorations (23).

These results differ from those obtained in the present study, in which the values of the group with the low viscosity resin were higher than the control group, although there was no statistically significant difference. This can be explained by the high percentage of organic matrix of flowable composites that increase the shrinkage stress $(3,10)$. So this could encourage the creation of an elastic layer in the cervical margins, just having high polymerization shrinkage, generating high stress at the interface of bonding (10). This is in accordance to Castañeda-Espinosa et al. (24), who described that the use of a flowable composite as an intermediate layer $(0.5$ or $1 \mathrm{~mm})$ promoted an increase in shrinkage stress force values.

The G3 (pre-cured spheres) had the lowest extent of penetration of the dye when compared with other groups, although this was not statistically significant. These data are in agreement with those obtained by Conceição et al. (7), in an in vitro study, which examined four techniques restored with CR in Class II cavities. In the group that was used in pre-polymerized portions of $\mathrm{CR}$, there was increased ability to limit leakage of dye (7). The CR spheres probably decreased the shrinkage of volume and linear polymerization of CR and, if allowed to exert pressure against the walls of the material of the cavity, facilitating its adaptation as well as obtaining a point of contact (7). In this context, this technique can be an alternative to be used in complex clinical cases, especially when gingival wall is located in dentin or cement substrate.

The null hypothesis was not rejected because there were not differences among marginal microleakage of $\mathrm{CR}$ with respect to restorative techniques. Although some studies used a smaller number of specimens per group $(9,21)$ or the same amount $(17,19)$ than the present study, our data showed high standard deviation values. It is possible that a larger sample size per group could lead to significant differences, especially in the group 3 .

\section{Conclusions}

Under the conditions of this in vitro study, it can be concluded that the marginal microleakage values were not influenced by the different restorative techniques tested.

\section{Acknowledgments}

The authors would like to acknowledge Núbia Miranda Ferreira (Dentsply) for supplying the material.

\section{References}

1. Dietrich TH, Lösche AC, Lösche GM, Roulet JF. Marginal adaptation of direct composite and sandwich restorations in class II cavities with cervical margins in dentine. J Dent 1999;27:1 19-28.

2. Kidd EA. Microleakage: a review. J Dent 1976;4:199-206.

3. Lopes LG, Franco EB, Mondelli RF, Souza Jr MH, Lauris JR. Evaluation of the effect of the cavity configuration factor on the marginal microleakage of the aesthetic restorative materials. Am J Dent $2003 ; 6: 211-4$
4. Santos GO, Silva AH, Guimarães JGA, Barcellos AAL, Sampaio EM, Silva EM. Analysis of gap formation at tooth-composite resin interface: effect of C-factor and light-curing protocol. J Appl Oral Sci 2007; 15:270-4.

5. Santos MJ, Silva e Souza Júnior MH, Santos Júnior GC, El-Mowafyn $O$, Cavalcanti APC, Neme CF. The influence of light intensity and curing cycle on microleakage of class $\mathrm{V} C \mathrm{R}$ restorations. J Appl Oral Sci 2005;13:193-7. 
6. Yoshikawa T, Burrow MF, Tagami J. A light curing method for improving marginal sealing and cavity wall adaptation of resin composite restorations. Dent Mater 2001;17:359-66.

7. Conceição EM, Vidor MM, Pacheco JFM, Manfredi DAB. Capacidade de selamento marginal de diferentes técnicas restauradoras com resina composta em dentes posteriores. Rev Fac Odontol Porto Alegre 1997;38:20-2.

8. Portero OO, Grullón PG, Ditterich RG, Gomes OMM, Gomes JC. A utilização das fibras de reforço na Odontologia. Publ UEPG Ci Biol Saúde 2005; 1 1:47-52.

9. Xu HHK, Schumacher GE, Eichmiller FC, Peterson RC, Antonucci JM, Mueller HJ. Continuous-fiber perform reinforcement of dental resin composite restorations. Dent Mater 2003;19:523-30.

10. Franco EB, Lopes LG. Conceitos atuais na polimerização de sistemas restauradores resinosos. Biodonto 2003;1:1-59.

11. Kenshima S, Grande RHM, Singer JM, Ballester RY. Effect of thermal cycling and filling technique on leakage of composite resin restoration. J Appl Oral Sci 2004;12:307-1 1 .

12. Lima FG, Romano AR, Correa MB, Demarco FF. Influence of microleakage, surface roughness and biofilm control on secondary caries formation around composite resin restorations: an in situ evaluation. J Appl Oral Sci 2009;17:61-5.

13. Cunha LG, Alonso RC, Souza-Júnior EJC, Neves AC, CorrerSobrinho L, Sinhoreti MA. Influence of the curing method on the post-polymerization shrinkage stress of a composite resin. J Appl Oral Sci 2008; 16:266-70.

14. Braga RR, Ballester RY, Ferracane JL. Factors involved in the development of polymerization shrinkage stress in resin-composites: a systematic review. Dent Mater 2005;21:962-70.

15. Going RE. Microleakage around dental restorations: a summarizing review. J Am Dent Assoc 1972;84:1349-57.
16. Cenci MS, Pereira-Cenci T, Donassollo TA, Sommer L, Strapassom A, Demarco FF. Influence of thermal stress on marginal integrity of restorative materials. J Appl Oral Sci 2008;16:106-10.

17. Schuckar M, Geurtsen W. Proximo-cervical adaptation of class II - composite restorations after termocycling: a quantitative and qualitative study. J Oral Rehab 1997;24:766-75.

18. Soares CJ, Celiberto L, Dechichi P, Fonseca RB, Martins LR. Marginal integrity and microleakage of direct and indirect composite inlays - SEM and stereomicroscopic evaluation. Braz Oral Res 2005; 19: 295-301.

19. Ernst CP, Galler P, Willershausen B, Haller B. Marginal integrity of class $V$ restorations: SEM versus dye penetration. Dent Mater 2008;24:319-27.

20. Pazinatto FB, Campos BB, Costa LC, Atta MT. Effect of the number of thermocycles on microleakage of resin composite restoration. Pesqui Odontol Bras 2003;17:337-41.

21. Li $Q$, Jepsen S, Albers H-K, Eberhard J. Flowable materials as an intermediate layer could improve the marginal and internal adaptation of composite restorations in class-V-cavities. Dent Mater 2006;22:250-7.

22. Chuang SF, Jin Y-T, Liu J-K, Chang C-H, Shieh D-B. Influence of flowable composite lining thickness on class II composite restorations. Oper Dent $2004 ; 29: 301-8$.

23. Alonso RCB, Sinhoreti MAC, Sobrinho LC, Consani S, Goes MF. Effect of resin liners on the microleakage of class $V$ dental composite restorations. J Appl Oral Sci 2004;12:56-61.

24. Castañeda-Espinosa JC, Pereira RA, Cavalcanti AP, Mondelli RFL. Transmission of composite shrinkage stress force through a flowable composite and a resin modified glass ionomer cement. J Appl Ora Sci 2007; 15:495-500. 